partidos e grupos políticos. Essas dimensões estão sintetizadas no campo que chamamos de gestão da empresa, onde aparece um outro conflito: o das velhas práticas (oriundas da antiga Usina Catende patronal) com as novas (mecanismos de participação do Projeto Harmonia-Catende).

Concluímos que a autogestão do Projeto Harmonia-Catende foi construída por um conjunto de soluções não planejadas, que visavam responder à luta por direitos daqueles sujeitos. Na raiz dessas soluções encontra-se a formação de movimentos sociais e sindicais que se desenvolveram naquela região, com o apoio da Igreja.

Palavras-chave: autogestão, economia solidária, socialismo, capitalismo, sindicalismo rural, movimentos sociais, Zona da Mata, Pernambuco

\title{
Infra-Estrutura de Chaves Públicas brasileira (ICP-Brasil) e a formação do Estado Eletrônico
}

\author{
Marcello Cavalcanti Barra
}

Curso: Mestrado em Sociologia

Data da defesa: 28 de agosto de 2006

Orientadora: $\operatorname{Prof}^{\mathrm{a}} \mathrm{Dr}^{\mathrm{a}}$ Fernanda Antonia da Fonseca Sobral

\section{Resumo}

Partiu-se da seguinte pergunta: como foi possível surgir o governo eletrônico? Para buscar respondê-la, recorreu-se a um estudo de caso. Pertencente ao campo da Sociologia da Ciência 
e Tecnologia, verificou-se qual a manifestação tecnológica mais citada em legislação do governo eletrônico. Chegou-se então à Infra-Estrutura de Chaves Públicas brasileira (ICP-Brasil), que contém a tecnociência da criptografia. $\mathrm{O}$ caso mostrou que a noção de governo eletrônico era insuficiente para explicar o que acontecera no processo de formação e implantação da ICP-Brasil. Criou-se, então, o conceito de Estado eletrônico (e-Estado), que é inédito na literatura.

Um conjunto de condições sociopolíticas, sociocognitivas e socioeconômicas, que se verificaram todas imbricadas umas às outras, proporcionou a instituição da ICP-Brasil. Foram precondições sociocognitivas: o conhecimento jurídico, o conhecimento tecnocientífico e a língua inglesa. $\mathrm{O}$ apoio proporcionado pelos bancos configurou a precondição socioeconômica. Emergindo o Leviatã, a condição sociopolítica consistiu na Razão de Estado. Esta envolveu a própria existência do Estado, a questão da segurança, as relações internacionais, a política nacional e internacional, a técnica, a Internet. Como precondições sociopolíticas da ICP-Brasil, identificaram-se outros papéis do Estado: o Estado Relacional, o Estado Instituidor do Social e o Estado Legislador.

A instituição da ICP-Brasil resultou de processos políticos. Além da Razão de Estado, vieram à tona a relação entre Estado e sociedade e entre técnica e política. Quanto à primeira, um dos resultados encontrados foi o surgimento de um nacionalismo turvo e de um nacionalismo sustentável, diante do contexto que se apresentou. Quanto à relação entre técnica e política, observaram-se diversas configurações dos papéis técnico e político. Dentre elas, dois atores assumiram os tipos de político-conector e técnico-conector, que expressam a ligação entre os dois papéis. Ao final, configurouse o Leviatã eletrônico, como parte do Leviatã, em resposta à nova realidade que a Internet impunha ao Estado.

Palavras-chave: Estado eletrônico, Leviatã eletrônico, governo eletrônico, Internet, Estado, ICP-Brasil, relação entre Estado e 
sociedade, relação entre técnica e política, condição de surgimento, tecnologia, ciência, tecnociência, conhecimento, híbrido, política, economia, atores sociais, Direito, segurança, nacionalismo, nacionalismo turvo, nacionalismo sustentável, político-conector, técnico-conector, Estado Relacional, Estado Instituidor do Social, Estado Legislador.

\section{Valores e democracia em Cabo-Verde: entre adesão formal e embaraço cultural}

Leão Domingos Jesus Lopes de Pina

Curso: Mestrado em Sociologia

Data da defesa: 26 de setembro de 2006

Nome do Orientador: Prof. Dr. Luís Augusto de Sarmento Gusmão

\section{Resumo}

Esta dissertação consiste numa descrição da cultura política cabo-verdiana atual e na sugestão de algumas de suas implicações para o sistema político democrático. A suposição de que essa cultura política tem no "perfil particularista" um de seus traços básicos se mostrou plausível, dado existir naquela sociedade uma indisposição (subjetiva) generalizada para se interagir cotidianamente com os concidadãos e com a maioria das instituições sociopolíticas. Evita-se a esfera pública e, muito provavelmente, privilegia-se, no estabelecimento de relações sociais e políticas, lógicas imanentes de ambientes privados (como a família), onde se encontra mais segurança, previsibilidade e reciprocidade. Disso advém a secundarização das regras universalistas, que é contrária aos pressupostos democráticos formais e institucionalmente estabelecidos. Tal imagem não condiz semanticamente com a percepção comum que se tem da categoria Morabeza - espécie de uma "supercordialidade 